\title{
Organic carbon distribution and water column respiration in the NW Africa-Canaries Coastal Transition Zone
}

\author{
Javier Arístegui ${ }^{1, *}$, Eric D. Barton ${ }^{2}$, María F. Montero ${ }^{1}$, Mercedes García-Muñoz ${ }^{1}$, \\ José Escánez ${ }^{3}$ \\ ${ }^{1}$ Facultad de Ciencias del Mar, Campus Universitario de Tafira, Universidad de Las Palmas de Gran Canaria, \\ 35017 Las Palmas de Gran Canaria, Spain \\ ${ }^{2}$ School of Ocean Sciences, University of Wales Bangor, Menai Bridge, Anglesey LL59 5AB, UK \\ ${ }^{3}$ Instituto Español de Oceanografía, Carretera de San Andrés s/n, 38120 Santa Cruz de Tenerife, Spain
}

\begin{abstract}
The Canary Current $(\mathrm{CC})$ is characterised by strong disruption of its flow by the Canaries Archipelago, which extends across the prevailing flow. In the Coastal Transition Zone (CTZ) downstream of the islands, a region of high mesoscale activity connects the eutrophic waters of the NW Africa coastal upwelling (UW) system with the oligotrophic open ocean waters of the eastern subtropical North Atlantic gyre (ESNA). We studied the distribution of particulate (POC) and dissolved organic carbon (DOC) and carbon remineralization rates in the 0 to $1000 \mathrm{~m}$ water column of this transitional region to assess its role in horizontal and vertical export of organic matter. The epipelagic waters $(0$ to $200 \mathrm{~m})$ of the CTZ are characterised by higher mean surface integrated concentrations of POC $\left(0.8 \pm 0.4 \mathrm{~mol} \mathrm{C} \mathrm{m}^{-2}\right)$ and DOC $\left(17 \pm 7 \mathrm{~mol} \mathrm{C} \mathrm{m}^{-2}\right)$, and by higher community respiration $\left(\mathrm{R}>100 \mathrm{mmol} \mathrm{C} \mathrm{m}{ }^{-2} \mathrm{~d}^{-1}\right)$ than the ESNA or UW waters. Integrated $\mathrm{R}$ was much lower $(7 \pm$ $3 \mathrm{mmol} \mathrm{C} \mathrm{m}^{-2} \mathrm{~d}^{-1}$ ) in the mesopelagic zone (200 to $1000 \mathrm{~m}$ ), indicating that most of the organic matter was respired in the upper $200 \mathrm{~m}$, with little being transported downwards. Nevertheless, peaks in DOC and $\mathrm{R}$ were observed at 300 to $600 \mathrm{~m}$ depth, coinciding with the depth of the deep scattering layer. These relative maxima were particularly important in the case of DOC, reaching concentrations comparable to surface waters $(>80 \mu \mathrm{M})$. In spite of this, DOC contributed only $26.5 \%$ to the apparent oxygen utilisation (AOU) in the mesopelagic zone. Correlations between R and particulateand dissolved organic matter suggest that respiration was mainly supported by particulate material at surface and deep waters. We compared plankton metabolic balances along the UW, CTZ and ESNA. Our analyses show that during summer time, and probably during most of the year, the ESNA and CTZ behave as net heterotrophic regions. In spite of a relatively high primary production (P) favoured by mesoscale activity in the CTZ, plankton R clearly exceeds $\mathrm{P}$ as result of the excess carbon advected from the coastal UW. However, a significant amount of non-respired carbon must be transported from the CTZ to the open ocean to account for part of the surface metabolic imbalance between $\mathrm{P}$ and $\mathrm{R}$ reported for the ESNA.
\end{abstract}

KEY WORDS: Organic carbon - POC distribution - DOC distribution - water column respiration . AOU/DOC relationships · Carbon budget · Canary Current · Canaries CTZ region · NW Africa upwelling

\section{INTRODUCTION}

Recent studies on plankton metabolism in the Canary Current (CC) region agree in showing that this relatively low primary productivity $\left(\mathrm{P}<20 \mathrm{~mol} \mathrm{C} \mathrm{m}^{-2}\right.$ $\mathrm{yr}^{-1}$ ) region presents high community respiration rates ( $\mathrm{R}>20 \mathrm{~mol} \mathrm{C} \mathrm{m}^{-2} \mathrm{yr}^{-1}$ ) and an almost permanent metabolic imbalance $(\mathrm{P} / \mathrm{R}<1)$ in surface waters (Duarte et al. 2001, González et al. 2001, Serret et al. 2001, 2002, Robinson et al. 2002). Although the balance between $\mathrm{P}$ 
and R may be biased by limitations in the coverage of the spatial and temporal variability in the 2 metabolic rates, particularly in P (Arístegui \& Harrison 2002), a consistent metabolic deficit, like that observed in the subtropical NE Atlantic, can only be explained by a recurrent furnishing of organic material from more productive nearby ecosystems (Duarte \& Agustí 1998).

The NW African upwelling (UW), as well as other coastal UW systems in eastern boundary currents (EBC), may export excess organic matter to the open ocean by means of both Ekman transport and offshore extensions of the coastal jet (the so called 'upwelling filaments'). Numerous filaments, associated with the presence of capes, are distributed along the NW African coast. Because of their greater extension, the Cape Guir $\left(30.5^{\circ} \mathrm{N}\right)$ and Cape Blanc $\left(21^{\circ} \mathrm{N}\right)$ filaments are the most significant in terms of organic matter export (Gabric et al. 1993, Neuer et al. 2002), although the latter is more a consequence of the separation of the $\mathrm{CC}$ from the African coast, rather than a true coastal filament.

Another important source for production of organic matter and its potential export to the eastern subtropical North Atlantic (ESNA) is the Canary Islands region. Unlike other EBCs, the CC is perturbed by the Canary Islands which are located normally to the prevailing oceanic and atmospheric flows, from near the African coast $\left(13.5^{\circ} \mathrm{W}\right)$ to the open ocean waters of the subtropical gyre $\left(18^{\circ} \mathrm{W}\right)$ at $28^{\circ} \mathrm{N}$. Downstream of all the islands, cyclonic and anticyclonic eddies, generated year-round, are spun off following the path of the CC (Arístegui et al. 1994). The eddy field has been observed in temperature and chlorophyll $a(\mathrm{chl} a)$ satellite images reaching as far as the equatorial region. Cyclonic eddies help increase the organic matter content of the region by uplifting nutrient-rich waters in their cores, enhancing primary productivity (Arístegui et al. 1997, Barton et al. 1998, Basterretxea \& Arístegui 2000). Additionally, the eddy field may play a key role in the transfer of organic matter between the coast and the open ocean. Anticyclonic eddies may entrain water with high organic matter content, advected from upwelling filaments or cyclonic eddies (Arístegui et al. 1997), being eventually transported to the open ocean by successive exchanges through the eddy field. This complex hydrographic region downstream of the islands, which connects the coastal UW with the open ocean waters of the subtropical gyre, is termed the Canaries-CTZ (coastal transition zone) region.

To investigate the role of this CTZ in the remineralization and export of organic carbon, we sampled a section covering the eutrophic-oligotrophic productivity gradient from the African coast to the open ocean, during the summer period of high mesoscale activity. The section intersected several island eddies and an upwelling filament. We studied the horizontal and vertical distribution of particulate (POC) and dissolved organic carbon (DOC) in the region as well as the $\mathrm{R}$ associated with the surface and deep water fluxes of organic matter, with the aim of assessing the potential of this region as a pump of organic carbon offshore to the open ocean.

\section{MATERIALS AND METHODS}

Data sources. A zonal section of 25 stations was sampled from the coastal waters of the NW African UW system $\left(27.6^{\circ} \mathrm{N}, 13.3^{\circ} \mathrm{W}\right)$ to the open ocean waters of the ESNA gyre $\left(29.2^{\circ} \mathrm{N}, 18.9^{\circ} \mathrm{W}\right)$, during the FAX cruise (5 to 10 August 1999) on board the 'BIO Hespérides'. At each station, temperature, salinity and fluorescence were recorded down to $1000 \mathrm{~m}$ by means of a SeaBird 9-11+ CTD system, mounted on a General Oceanics rosette sampler equipped with twenty-four 12 l Niskin bottles. Samples for chl a and POC were collected at 7 depths, from surface to $200 \mathrm{~m}$. Samples for dissolved oxygen, DOC and microbial respiratory electron transport system (ETS) activity were collected at the same 7 depths and also at 8 additional depths down to $1000 \mathrm{~m}$.

Dissolved oxygen and chl a. Dissolved oxygen was analysed by Winkler titrations in accordance with the JGOFS recommendations (UNESCO 1994). Oxygen solubility was computed using the equations of Weiss (1970). Apparent oxygen utilisation (AOU, umol $\mathrm{O}_{2} \mathrm{~kg}^{-1}$ ) was calculated by subtracting measured oxygen concentration from the oxygen solubility values at saturation with respect to the atmosphere.

Chl a was estimated fluorometrically by means of a Turner Designs bench fluorometer, previously calibrated with pure chl a (Sigma), following the recommendations of Yentsch \& Menzel (1963). Seawater samples $(500 \mathrm{ml})$ were filtered through Whatman GF/F fibre filters. Pigments were extracted on board in cold acetone for $24 \mathrm{~h}$. For the final determination of chl $a_{\text {, }}$ the acetone extracts were acidified allowing chl $a$ and phaeopigment to be independently estimated. Extracted chl a samples were used to calibrate the voltage readings of the submersible fluorometer (Sea-Tech 57S) linked to the CTD unit.

POC and DOC. Samples (2 l) for POC were filtered through pre-combusted $\left(450^{\circ} \mathrm{C}, 12 \mathrm{~h}\right) 25 \mathrm{~mm}$ Whatman GF/F filters. The filters were wrapped in precombusted aluminium foil and frozen at $-20^{\circ} \mathrm{C}$ until being processed a few weeks later. In the laboratory, the filters were thawed and dried overnight at $65^{\circ} \mathrm{C}$ and packed in pre-combusted nickel sleeves. The carbon analyses were performed on a Perkin Elmer2400 CHN elemental analyser (UNESCO 1994). 
Water samples $(10 \mathrm{ml})$ for the analysis of total organic carbon (TOC) were dispensed directly from the Niskin bottles into pre-combusted $\left(500^{\circ} \mathrm{C}, 12 \mathrm{~h}\right)$ glass ampoules. The samples were immediately acidified with $50 \mu \mathrm{l}$ of $50 \% \mathrm{H}_{3} \mathrm{PO}_{4}$, sealed, and stored at 2 to $4^{\circ} \mathrm{C}$ until analysed (Sharp \& Peltzer 1993). TOC concentrations were measured using a Shimadzu TOC5000 analyser. At the beginning of each analysis run, the sample was sparged with $\mathrm{CO}_{2}$-free air for several minutes to remove the inorganic carbon. The sample was then injected ( 3 replicates of $100 \mu \mathrm{l}$ ) into a quartz tube with a platinum catalyst and then combusted at $680^{\circ} \mathrm{C}$. TOC concentrations were determined from standard curves (30 to $200 \mu \mathrm{M} \mathrm{C}$ ) of potassium hydrogen phthalate produced every day (Thomas et al. 1995). TOC reference material prepared in the laboratory of Jonathan H. Sharp (University of Delaware) was analysed every day to check for the accuracy and precision of our instrument. We obtained an average concentration of $44.5 \pm 2.7 \mu \mathrm{M} \mathrm{C}(\mathrm{n}=31)$ for the deep ocean reference (Sargasso Sea deep water, $2600 \mathrm{~m}$ ) and $0.21 \pm 0.53 \mu \mathrm{M} \mathrm{C}(\mathrm{n}=31)$ for the blank reference material, whose nominal values were $44.0 \pm 2.7$ and $0.0 \pm 1.5 \mu \mathrm{M} \mathrm{C}$, respectively. DOC was finally computed by subtracting POC from TOC.

ETS and R measurements. Depending on depth, 5 to $20 \mathrm{l}$ of seawater were pre-filtered through a $200 \mu \mathrm{m}$ mesh and poured into acid-cleaned plastic carboys, before being filtered through $47 \mathrm{~mm}$ Whatman GF/F filters, at a low vacuum pressure $(<1 / 3 \mathrm{~atm})$. The filters were immediately stored in liquid nitrogen until being assayed in the laboratory within a few weeks. ETS determinations were carried out according to the Kenner \& Ahmed (1975) modification of the tetrazolium reduction technique proposed by Packard (1971) as described in Arístegui \& Montero (1995). An incubation time of $20 \mathrm{~min}$ at $18^{\circ} \mathrm{C}$ was used. ETS activities measured at $18^{\circ} \mathrm{C}$ were converted to activities at in situ temperatures by using the Arrhenius equation. A mean activation energy of $16 \mathrm{kcal} \mathrm{mol}^{-1}$ was used (Arístegui \& Montero 1995).

Community $\mathrm{R}$ in the upper $200 \mathrm{~m}$ was estimated from the respiratory ETS activity, using the general equation $\log \mathrm{R}=0.357+0.750 \log \mathrm{ETS}\left(\mathrm{r}^{2}=0.75, \mathrm{n}\right.$ = 197) obtained by Arístegui \& Montero (1995) for surface oceanic waters. This equation yields a mean error in the prediction of $\pm 34 \%$. A respiratory quotient $\left(\mathrm{CO}_{2}\right.$ to $\mathrm{O}_{2}$ ratio) of 0.8 (Robinson et al. 2002) was used to convert oxygen values into carbon units $\left(\mathrm{R}_{<200}\right)$.
$\mathrm{R}$ in the 200 to $1000 \mathrm{~m}$ layer $\left(\mathrm{R}_{>200}\right)$ was calculated from the oxygen consumption rates, using a $\mathrm{CO}_{2}$ to $\mathrm{O}_{2}$ molar respiratory quotient of 0.69 (Hedges et al. 2002). The oxygen consumption rate was obtained from ETS activity using an $\mathrm{R}$ to ETS conversion factor of 0.086 (Christensen et al. 1980, Packard et al. 1988). According to Packard et al. (1988), the error associated with $\mathrm{R}_{>100}$ calculation from ETS activity is about $30 \%$.

\section{RESULTS}

\section{Regional oceanographic setting}

The waters of the region of study were strongly influenced by the presence of mesoscale structures. Up to 14 cyclonic and anticyclonic eddies along with 4 upwelling filaments were observed downstream of the islands in the CTZ between the NW African coast and the open ocean waters (E. D. Barton et al. unpubl.). Our study section (Fig. 1) intersected 4 of these cyclonic eddies (C2, C3, C5 and C7), 1 anticyclonic eddy (A1) and one of the upwelling filaments (F1). Particularly noticeable was the cyclonic/anticyclonic eddy pair (C5/A1) observed south of Tenerife and Gomera Islands, where isotherms and isohalines showed vertical excursions in the frontal boundary between the eddies of about $200 \mathrm{~m}$. The influence of these eddies in the temperature and salinity field was observed down to $800 \mathrm{~m}$ (Fig. 2). At the eastern side of the section, the filament F1 wrapped around the cyclonic eddy C7, most of the filament water was returned shoreward

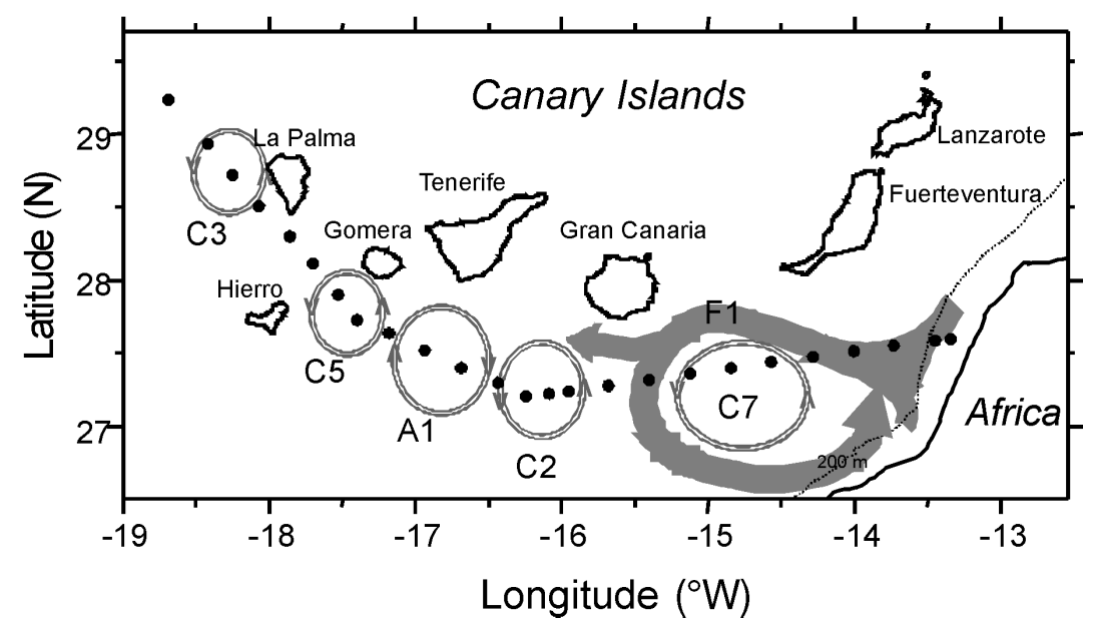

Fig. 1. Canary Islands region showing the stations sampled $(\bullet)$ along a section, extending from the NW African coastal upwelling waters $(<200 \mathrm{~m})$ to the open ocean waters of the eastern subtropical gyre (west of La Palma Island). The section intersected 4 cyclonic eddies (C2, C3, C5 and C7), 1 anticyclonic eddy (A1) and 1 upwelling filament (F1). The surface flow of F1 is approximately represented by a broad grey arrow 

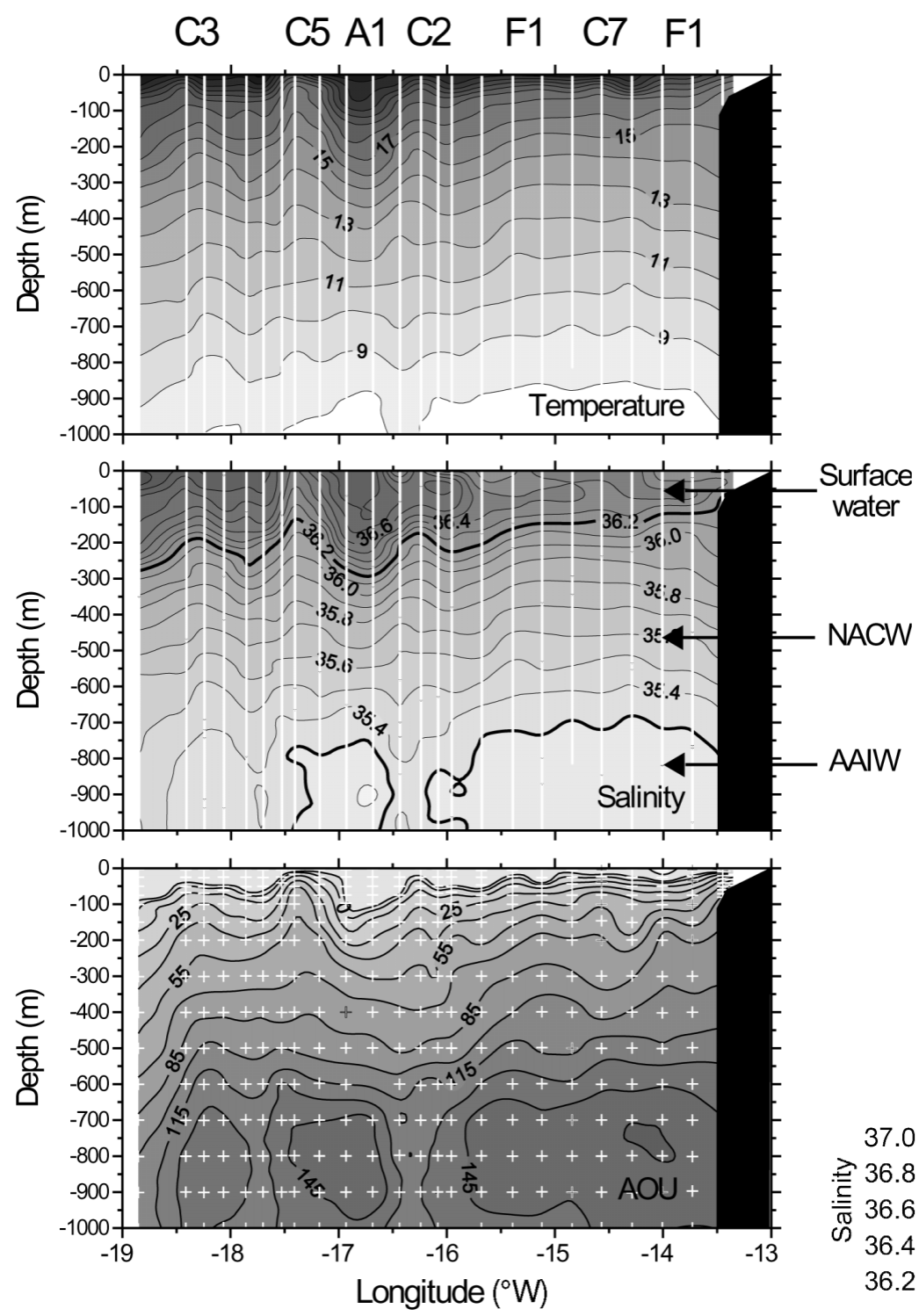

Fig. 2. Vertical distributions (0 to $1000 \mathrm{~m}$ ) of temperature $\left({ }^{\circ} \mathrm{C}\right)$,

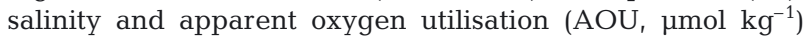
along the section. NACW $=$ North Atlantic central water; AAIW $=$ Antarctic intermediate water

(Fig. 1; E. D. Barton et al. unpubl.). The meridional component of currents (Fig. 3) measured with the shipborne acoustic Doppler current profiler revealed the strong azimuthal velocities associated with the various eddies, identifiable here by their surface salinity signal. The lower salinity filament waters, labelled F1, crossed the section southwards at the outer edge of cyclonic eddy C7. Recirculation was indicated by weak northward flow close to the slope and shelf. The separation between lower salinity CTZ and UW waters and higher salinity ESNA waters was evident at around $15.5^{\circ}$ to $16^{\circ} \mathrm{W}$. The $\mathrm{C} 7-\mathrm{F} 1$ system largely recycles the offshore filament transport back to the shelf (Barton et al. 1998) or interacts with cyclonic eddies (Barton et al. 2000) and anticylonic eddies (Basterretxea et al. 2002) spun off Gran Canaria. In the latter cases, filament waters were entrained around the eddies to be introduced further offshore. At the westernmost extreme of the section, the isolines of temperature and salinity sink down, suggesting downwelling of water, presumably by the presence of a frontal structure (Fig. 2).

Underlying the surface waters, North Atlantic central water (NACW) extended down to 700 to $800 \mathrm{~m}$, occupying most of the vertical depth range of our sampling. Below the NACW, parcels of Antarctic intermediate water (AAIW), with lower salinity $(<35.3 \mathrm{psu})$ and higher AOU $\left(>130 \mu \mathrm{mol} \mathrm{O}_{2} \mathrm{~kg}^{-1}\right)$ than the $\mathrm{NACW}$, were observed along the whole section.

\section{Distributions of organic matter and ETS activity}

POC and chl a showed the highest values ( $>10 \mu \mathrm{M}$ and $>10 \mathrm{mg} \mathrm{m}^{-3}$, respectively) in the surface waters of the 2 coastal upwelling stations (Fig. 4). Maxima of the 2 biological properties were also observed in cyclonic eddies C5 and $\mathrm{C} 7$ and in filament waters.

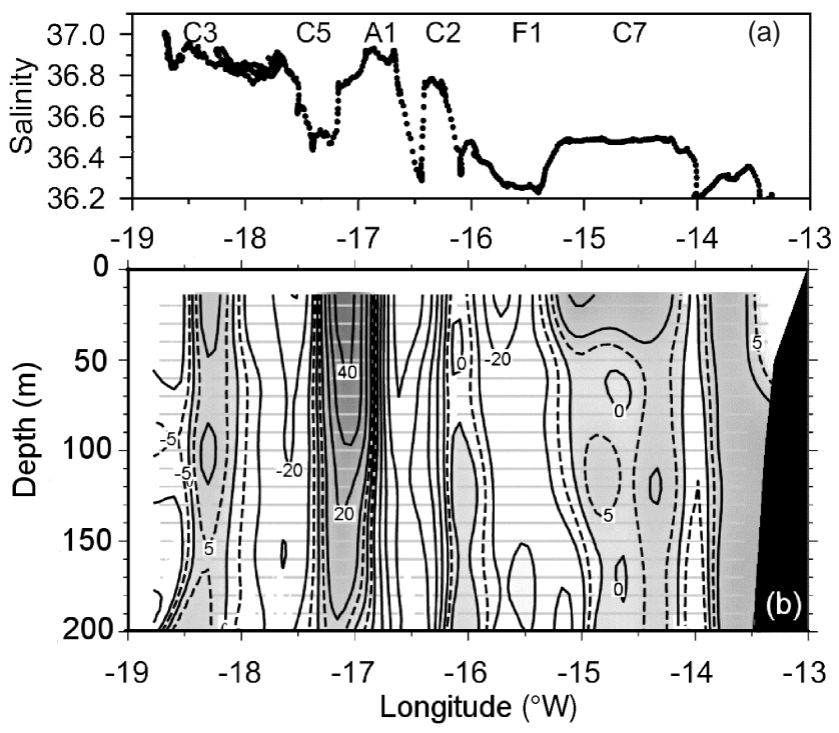

Fig. 3. (a) Surface salinity along the station line of Fig. 1. Anticyclonic (A) and cyclonic (C) eddy positions are marked along with the filament F1. (b) Northward component of absolute velocity measured by ship-borne acoustic Doppler current profiler (ADCP). Velocities are expressed in $\mathrm{cm} \mathrm{s}^{-1}$. Northward flow is indicated by grey fill. Horizontal dotted lines show ADCP bin depths 
The chl a maximum (CM) showed a tendency to deepen progressively from coastal to open ocean waters, but the perturbation of the thermocline waters by island eddies elevated the CM to the surface in eddy C5 and depressed it to $>100 \mathrm{~m}$ in eddy A1. At the westernmost stations, the CM deepened to $100 \mathrm{~m}$, following the isotherms and coinciding with a relative maximum in POC at this depth (Fig. 4).

DOC displayed, to a large extent, a contrasting pattern of distribution to POC and chl a (Fig. 4). Coastal waters and waters associated with cyclonic eddies (where upwelling is produced) presented relatively low DOC values $(<70 \mu \mathrm{M})$. The highest DOC concentrations $(>100 \mu \mathrm{M})$ were observed in those regions where water convergence and downwelling were presumably produced, i.e. the anticyclone A1 (although the station at the core of the eddy was not sampled for DOC) and those stations near the upwelling boundary where water recirculated shoreward $\left(14\right.$ to $14.5^{\circ} \mathrm{W}$; Fig. 1). These high concentrations are comparable to the highest DOC values observed in particular oceanic regions where $\mathrm{P}$ is elevated and surface warming enhances upper layer stratification (Hansell 2002).

Respiratory ETS activity was in general high $\left(>0.7 \mathrm{mmol} \mathrm{O}_{2} \mathrm{~m}^{-3} \mathrm{~d}^{-1}\right.$ ) in the upper $50 \mathrm{~m}$ of the section, decreasing sharply below 100 to $150 \mathrm{~m}$ (Fig. 4). The lowest values were observed at the boundary between the filament waters and the open ocean waters (15.5 to $16^{\circ} \mathrm{W}$ ), and the highest (up to $5 \mathrm{mmol} \mathrm{O}_{2} \mathrm{~m}^{-3} \mathrm{~d}^{-1}$ ) in the upper $20 \mathrm{~m}$ of the coastal stations. Relative ETS maxima were also associated with the surface waters of eddies C5 and C7, and through the upper $150 \mathrm{~m}$ in eddy A1.

Both DOC and ETS activity showed subsurface maxima in the mesopelagic zone $(>200 \mathrm{~m})$ at the same stations in the depth range (300 to $600 \mathrm{~m}$; Fig. 5). While the deep peaks in DOC were almost of the same magnitude as the surface values $(>80 \mu \mathrm{M})$, the magnitude of the ETS maxima in deep waters $\left(\sim 0.2 \mathrm{mmol} \mathrm{O}_{2} \mathrm{~m}^{-3}\right.$ $\mathrm{d}^{-1}$ ) was considerably lower than that of surface waters $\left(>1 \mathrm{mmol} \mathrm{O}_{2} \mathrm{~m}^{-3} \mathrm{~d}^{-1}\right)$.
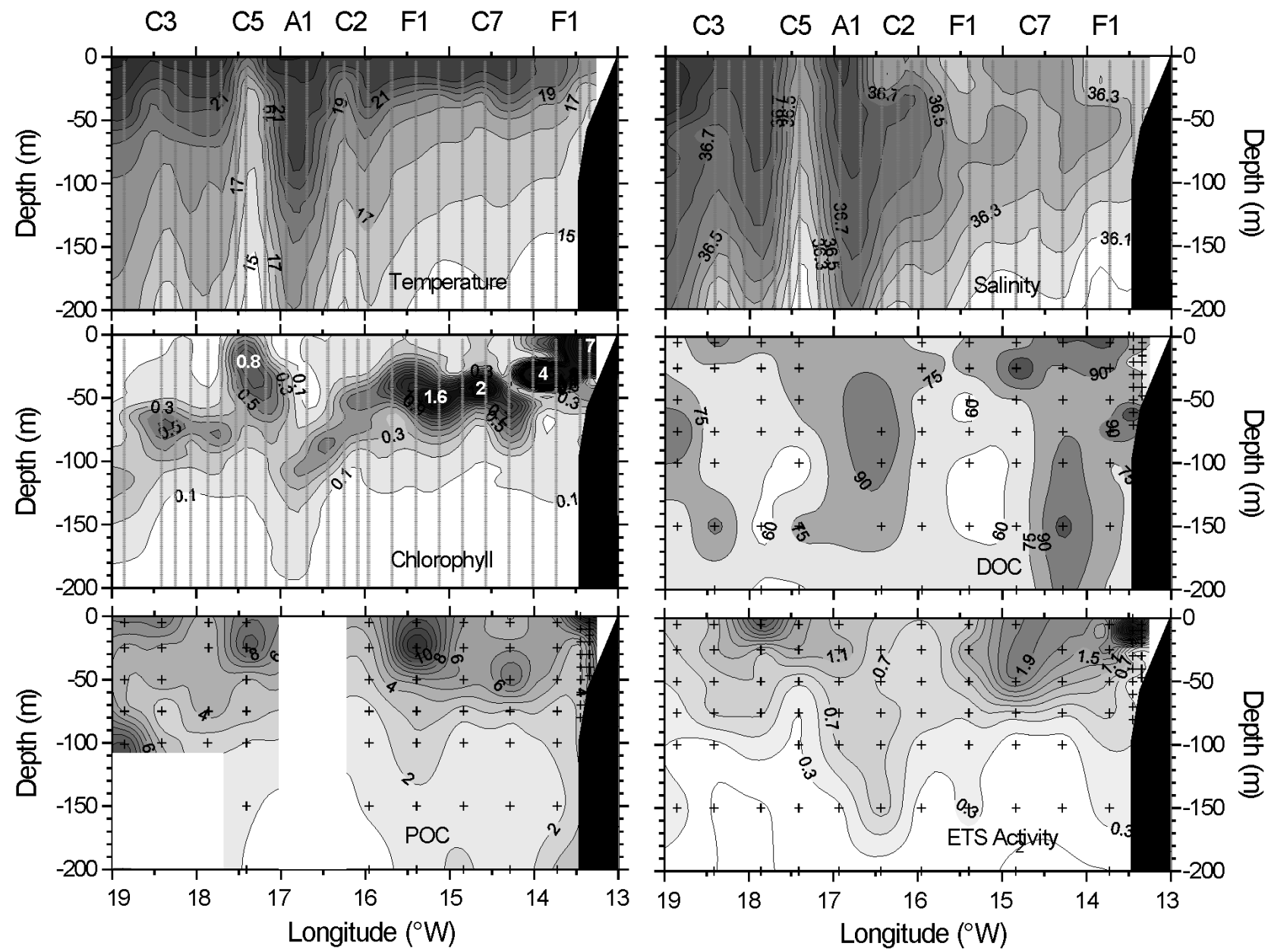

Fig. 4. Vertical distributions of temperature $\left({ }^{\circ} \mathrm{C}\right)$, salinity, chlorophyll a $\left(\mathrm{mg} \mathrm{m}^{-3}\right)$, dissolved organic carbon $(\mathrm{DOC}, \mu \mathrm{M})$, particulate organic carbon (POC, $\mu \mathrm{M})$ and respiratory electron transport system (ETS) activity $\left(\mathrm{mmol} \mathrm{O}_{2} \mathrm{~m}^{-3} \mathrm{~d}^{-1}\right)$ in the upper water column (0 to $200 \mathrm{~m}$ ) 


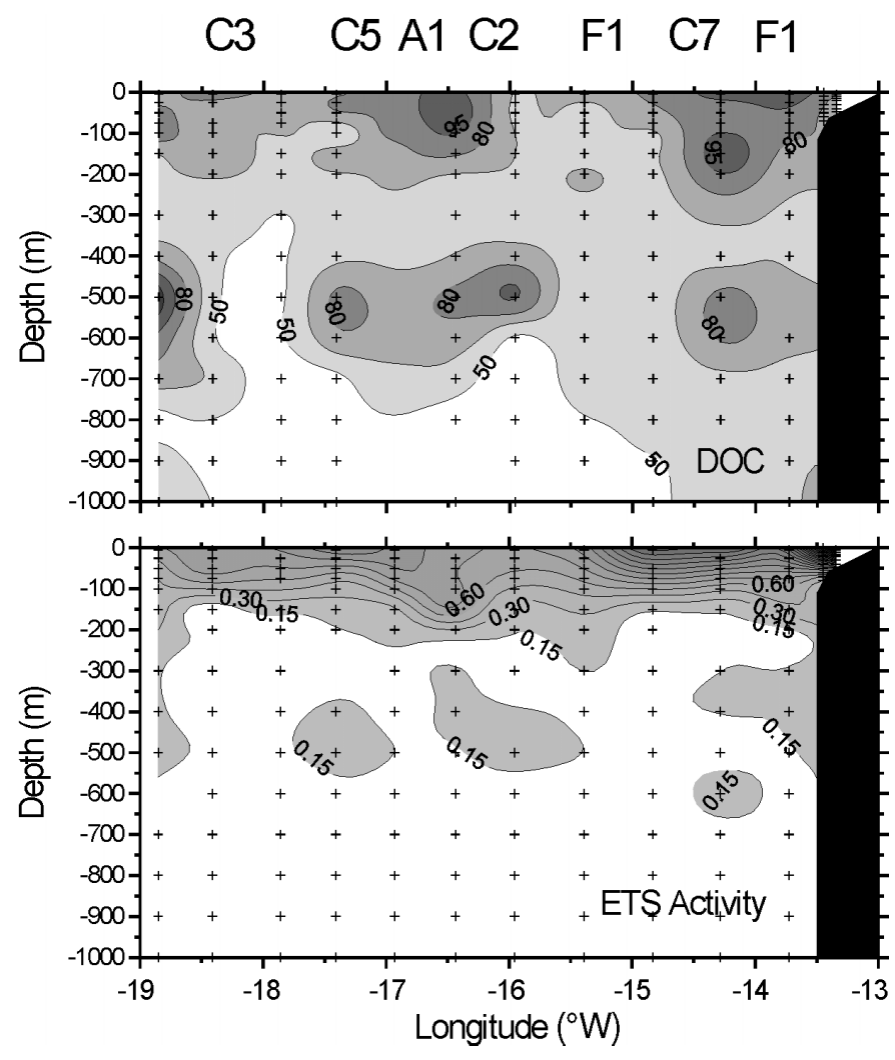

Fig. 5. Vertical distributions (0 to $1000 \mathrm{~m})$ of (DOC, $\mu \mathrm{M})$ and respiratory electron transport system (ETS) activity $\left(\mathrm{mmol} \mathrm{O}_{2}\right.$ $\mathrm{m}^{-3} \mathrm{~d}^{-1}$ ). Notice the relative maxima in dissolved organic carbon (DOC) and ETS in the mesopelagic zone, coinciding with the depth at which the deep scattering layer has been reported

\section{Correlation between variables}

Respiratory ETS activity was correlated in the upper $200 \mathrm{~m}$ with both particulate material (POC and chl a) and DOC. The correlation was stronger with POC ( $\mathrm{r}=$ 0.63, $\mathrm{p}<0.0001, \mathrm{n}=72)$ and $\mathrm{chl} a(\mathrm{r}=0.55, \mathrm{p}<0.0001$, $\mathrm{n}=89$ ) than with DOC $(\mathrm{r}=0.35, \mathrm{p}<0.01, \mathrm{n}=74)$, suggesting that respiration in surface waters was indirectly based on particulate organic matter, i.e. the more POC present the more solubilisation of labile DOC there is to support microbial R. The 2 fractions of organic carbon were not correlated (as may be inferred simply from their vertical distribution). Below $200 \mathrm{~m}$, DOC was significantly, but weakly, correlated with both ETS ( $\mathrm{r}=0.27, \mathrm{p}=0.014, \mathrm{n}=81)$ and AOU ( $\mathrm{r}=$ $-0.29, \mathrm{p}=0.01, \mathrm{n}=80$ ).

The relationship between DOC and AOU (Fig. 6) for AOU $>0$ (i.e. for waters below the thermocline) yields a slope (molar ratio) of $-0.183( \pm 0.03)$. By converting the AOU to carbon units (using a Redfield ratio $-\Delta \mathrm{C} / \Delta \mathrm{O}_{2}=0.69$; Hedges et al. 2002), we find that the DOC contributes $26.5 \%$ to the $\mathrm{AOU}$ in equivalent



Fig. 6. Relation between (dissolved organic carbon) DOC and apparent oxygen utilisation (AOU) for AOU values $>0$, described by the fitted regression equation: $\mathrm{DOC}=79.1( \pm 2.75)$ $-0.183( \pm 0.03)$ AOU $\left(R^{2}=0,24 p<0.0001, n=125\right)$

carbon units. Hence, the remainder must be due to oxidation of sinking POC. This value represents an upper boundary since the correlation of AOU and DOC is partly due to the effect of water masses mixing. In our case, however, DOC showed a weaker correlation with temperature $\left(\mathrm{R}^{2}=0.27, \mathrm{p}<0.0001, \mathrm{n}=152\right)$ than in other oceanic regions $\left(\mathrm{R}^{2}>0.7\right.$; Doval \& Hansell 2000, Arístegui et al. 2002), and the coefficient of regression between DOC and AOU (for AOU > 0) only increased from 0.24 to 0.27 when including temperature in the regression.

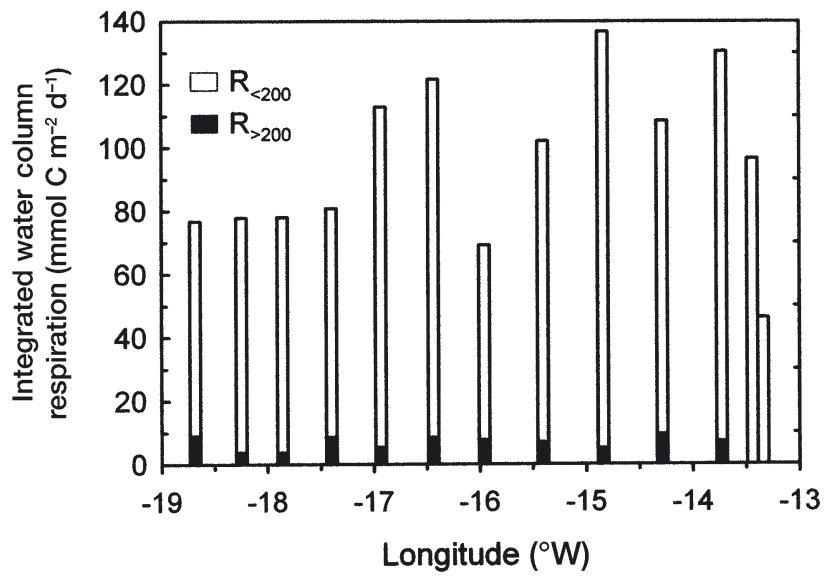

Fig. 7. Integrated water column respiration (R), expressed in carbon units $\left(\mathrm{mmol} \mathrm{C} \mathrm{m}{ }^{-2} \mathrm{~d}^{-1}\right)$, for the 0 to $200 \mathrm{~m}\left(\mathrm{R}_{<200}\right)$ and 200 to $1000 \mathrm{~m}\left(\mathrm{R}_{>200}\right)$ depth ranges. See details for conversions in 'Materials and methods'. The 2 easternmost stations corresponded to the coastal upwelling stations, and were integrated to the bottom (80 and $47 \mathrm{~m}$, respectively) 


\section{Water column respiration}

Calculated community $\mathrm{R}$ integrated in the upper $200 \mathrm{~m}$ (the epipelagic zone), and expressed in carbon


at the most oceanic station to $137 \mathrm{mmol} \mathrm{C} \mathrm{m}{ }^{-2} \mathrm{~d}^{-1}$ at one of the filament stations (median $=100 \pm 24 \mathrm{mmol}$ $\mathrm{C} \mathrm{m}^{-2} \mathrm{~d}^{-1}$ ). By comparison, integrated $\mathrm{R}$ below $200 \mathrm{~m}$ $\left(\mathrm{R}_{>200}\right)$ was considerably lower (median $=7 \pm 3 \mathrm{mmol}$ $\mathrm{C} \mathrm{m}^{-2} \mathrm{~d}^{-1}$ over all stations). This represents only $\sim 7 \%$ of the 0 to $1000 \mathrm{~m}$ water column respiration, and indicates that most of the labile organic matter is respired in surface waters. These estimates must be considered however with some degree of caution since deepwater $\mathrm{R}$ were calculated using a constant R/ETS ratio derived from empirical relationships with oxygen consumption rates determined from monospecific cultures of bacteria (Christensen et al. 1980, Packard et al. 1988). Nevertheless, the use of this conversion factor yields comparable results to oxygen utilisation rates computed from $\mathrm{AOU}$ and water mass age (Arístegui et al. 2003).

\section{DISCUSSION}

\section{Epipelagic plankton respiration and organic carbon fluxes in the Canary Islands region}

The microbial $\mathrm{R}$ integrated in epipelagic waters of our study section are high, but of the same magnitude as rates from previous studies in the same region (Table 1). For instance, Duarte et al. (2001) compiled respiration data (from in vitro oxygen experiments) ranging from NW Africa to the subtropical NE Atlantic, and estimated a similar mean $\mathrm{R}$ for the euphotic zone of $96 \pm 7 \mathrm{mmol} \mathrm{C} \mathrm{m}^{-2} \mathrm{~d}^{-1}(\mathrm{n}=33)$. Robinson et al. (2002) estimated (also from in vitro oxygen experiments) a mean euphotic zone $\mathrm{R}$ for 4 stations of the subtropical NE Atlantic of $111 \pm 34 \mathrm{mmol} \mathrm{C} \mathrm{m}{ }^{-2} \mathrm{~d}^{-1}$, which included 1 station close to the Canaries CTZ and another close to the Cape Blanc filament. Arístegui \& Montero (in press) observed, in oceanic waters south of Gran Canaria, an annual variation in plankton $\mathrm{R}$ (derived from ETS activity) integrated over the upper $150 \mathrm{~m}$ of less than a factor of 2 , with values comparable to the

Table 1. Compiled average integrated daily rates $\left(\mathrm{mmol} \mathrm{C} \mathrm{m}^{-2} \mathrm{~d}^{-1}\right)$ of primary production $(\mathrm{P})$ and epipelagic community respiration (R) from the eastern subtropical North Atlantic (ESNA), the Canaries Coastal Transition Zone (CTZ) and the NW African upwelling (UW) regions (Cape Guir and Cape Juby). Depth = maximum depth of integration; EZ = euphotic zone. Oxygen-based $\mathrm{P}$ and $\mathrm{R}$ were transformed to carbon units using, respectively, a photosynthetic quotient $=1.2$ and a respiratory quotient $=0.8$

\begin{tabular}{|c|c|c|c|c|c|}
\hline Region & Depth & Season & $\mathrm{P}$ & $\mathrm{R}$ & Source \\
\hline ESNA & EZ & Spring & $89^{b}$ & $96^{\mathrm{b}}$ & González et al. (2001) \\
\hline ESNA & EZ & Spring & $53^{\mathrm{b}}$ & $111^{\mathrm{b}}$ & Robinson et al. (2002) \\
\hline ESNA & EZ & Summer & $26^{\mathrm{b}}$ & $126^{\mathrm{b}}$ & González et al. (2001) \\
\hline ESNA & $200 \mathrm{~m}$ & Summer & & $78^{\mathrm{c}}$ & This study \\
\hline ESNA & EZ & Autumn & $54^{\mathrm{a}}$ & $62^{\mathrm{c}}$ & Arístequi \& Harrison (2002) \\
\hline ESNA & $\mathrm{EZ}$ & Autumn & $34^{\mathrm{b}}$ & $59^{\mathrm{b}}$ & Serret et al. (2002) \\
\hline \multicolumn{2}{|c|}{ ESNA (Median \pm SE) } & & $51 \pm 12$ & $89 \pm 12$ & \\
\hline CTZ & $150 \mathrm{~m}$ & Spring & $100^{\mathrm{a}}$ & $187^{\mathrm{c}}$ & Arístegui \& Montero (2003) \\
\hline CTZ & EZ & Summer & $30^{\mathrm{a}}$ & & Basterretxea \& Arístegui (2000) \\
\hline CTZ & $150 \mathrm{~m}$ & Summer & & $113^{\mathrm{c}}$ & Arístegui \& Montero (2003) \\
\hline CTZ & $200 \mathrm{~m}$ & Summer & & $108^{\mathrm{c}}$ & This study \\
\hline $\mathrm{CTZ}$ & $\mathrm{EZ}$ & Autumn & $26^{\mathrm{a}}$ & & Bode et al. (2001) \\
\hline \multicolumn{2}{|c|}{$\mathrm{CTZ}($ Median $\pm \mathrm{SE})$} & & $52 \pm 29$ & $136 \pm 31$ & \\
\hline UW (C. Guir) & EZ & Winter & $108^{\mathrm{a}}$ & & Minas et al. (1982) \\
\hline UW (C. Guir) & EZ & Summer & $200^{\mathrm{a}}$ & & Minas et al. (1982) \\
\hline UW (C. Guir) & EZ & Summer & $108^{\mathrm{a}}$ & & Grall et al. (1982) \\
\hline UW (C. Juby) & $\mathrm{EZ}$ & Summer & $200^{\mathrm{a}}$ & & Minas et al. (1982) \\
\hline UW (C. Juby) & $\mathrm{EZ}$ & Summer & $260^{\mathrm{a}}$ & & Basterretxea \& Arístegui (2000) \\
\hline UW (C. Juby) & $\mathrm{EZ}$ & Summer & $107^{\mathrm{b}}$ & $102^{\mathrm{b}}$ & Arístegui et al. (unpubl.) \\
\hline UW (C. Juby) & $\mathrm{EZ}$ & Summer & & $72^{\mathrm{c}}$ & This study \\
\hline UW (C. Guir) & $\mathrm{EZ}$ & Autumn & $136^{\mathrm{b}}$ & $72^{\mathrm{b}}$ & Arístegui \& Harrison (2002) \\
\hline \multicolumn{3}{|c|}{ UW (Median \pm SE) } & $160 \pm 25$ & $82 \pm 12$ & \\
\hline \\
\hline \multicolumn{6}{|c|}{$\begin{array}{l}{ }^{a} \mathrm{P} \text { derived from }{ }^{14} \mathrm{C} \text {-uptake experiments } \\
{ }^{\mathrm{b}} \mathrm{P} \text { (gross production) and } \mathrm{R} \text { derived from oxygen evolution experiments }\end{array}$} \\
\hline
\end{tabular}


highest rates found in our study $\left(\mathrm{R}_{<150}=113 \pm 18\right.$ to $187 \pm 87 \mathrm{mmol} \mathrm{C} \mathrm{m}^{-2} \mathrm{~d}^{-1}$ ).

In general, respiration values in the Canaries CTZ region are significantly higher than those recorded from most open ocean regions, and in particular from the central North Atlantic subtropical gyre. Indeed, Arístegui \& Harrison (2002) obtained a mean $\mathrm{R}=62 \pm$ $58 \mathrm{mmol} \mathrm{C} \mathrm{m}{ }^{-2} \mathrm{~d}^{-1}(\mathrm{n}=33)$ integrated over the upper $100 \mathrm{~m}$ along a trans-oceanic section crossing the oligotrophic North Atlantic ocean from Canada to the Canary Islands. This value is close to the 0 to $100 \mathrm{~m}$ integrated rates observed in the more oceanic stations

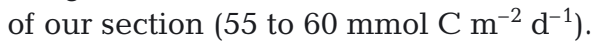

To account for the high $\mathrm{R}$ observed in the Canaries $\mathrm{CTZ}$, either the region is very productive and/or it receives high loadings of organic carbon exported from the coastal UW system. Estimates of P from the CTZ region are scarce and variable (Table 1 ). They range 4 -fold from $26 \mathrm{mmol} \mathrm{C} \mathrm{m}^{-2} \mathrm{~d}^{-1}$ in autumn to $100 \mathrm{mmol} \mathrm{C} \mathrm{m}^{-2} \mathrm{~d}^{-1}$ in spring time, although in the latter study 2 intense cyclonic eddies were sampled. Cyclonic eddies that are shed from islands (Arístegui et al. 1994, 1997) are known to upwell nutrient-rich deep water in their cores, increasing the surface productivity in relation to the ambient waters (Falkowski et al. 1991, Basterretxea \& Arístegui 2001). McGillicuddy et al. (1998) calculated that the vertical flux of nutrients in mesoscale eddies in the Sargasso Sea was sufficient to balance the nutrient budget in that region. The influence of cyclonic eddies on new production seems to be particularly important in the Canary Islands region, due to the yearly recurrence and intensity of eddies. Indeed, Barton et al. (1998) estimated that, due to the influence of cyclonic eddies, the Canaries region is 3 times as active in vertical transport of nitrogen as the mean of the global ocean. Whether the increase in $\mathrm{P}$ by eddy pumping is sufficient to account for the overall organic matter respired in the Canaries CTZ is however unclear. Basterretxea (1994) observed that P in the core of a cyclonic eddy in early stage of development in the Canaries could be as high as $200 \mathrm{mmol} \mathrm{C}$ $\mathrm{m}^{-2} \mathrm{~d}^{-1}$, although values in ambient waters were considerably lower, decreasing the average value for the region to about $100 \mathrm{mmol} \mathrm{C} \mathrm{m}{ }^{-2} \mathrm{~d}^{-1}$, well below the average $\mathrm{R}\left(187 \mathrm{mmol} \mathrm{C} \mathrm{m}^{-2} \mathrm{~d}^{-1}\right)$. Hence, although the overall influence of cyclonic eddies on regional $\mathrm{P}$ has been probably underestimated during past field studies, it seems reasonable to think that the large metabolic deficit observed in the balance between plankton P and R (Duarte et al. 2001, Robinson et al. 2002, Arístegui \& Montero in press) needs to be supported also by external inputs of organic matter.

The mean values of POC $\left(0.8 \pm 0.4 \mathrm{~mol} \mathrm{C} \mathrm{m}^{-2}\right)$ and DOC (17 $\left.\pm 7 \mathrm{~mol} \mathrm{C} \mathrm{m}^{-2}\right)$ integrated (0 to $200 \mathrm{~m}$ ) along our study section are significantly higher than values observed in the open ocean subtropical gyre waters (Hansell \& Carlson 2001, Harrison et al. 2001, Steinberg et al. 2001). Part of this organic matter may be advected from the coastal UW system by both upwelling filaments and Ekman transport. Filaments rich in chl a have been documented in several studies to stretch several $100 \mathrm{~km}$ offshore into the Canaries region, interacting with island eddies shed from the islands (Arístegui et al. 1997). Neuer et al. (2002) observed that the Cape Guir filament, north of the Canary Islands, transported particles of shelf origin to sediment traps deployed as far as $700 \mathrm{~km}$ offshore.

Additionally, at some times of the year, and coinciding with a weakening in wind intensity or a shift in wind direction, satellite images show a broad spreading of chl a from the coastal UW into the Canaries region (e.g. Arístegui et al. 1997, Pacheco \& Hernández-Guerra 1999). This is presumably linked to reversals in the main flow, which allow the presence of a northward flow from Cape Blanc to Cape Juby, diverting westwards at this latitude (Pelegrí et al. in press). These flow diversions are more frequent during late fall and winter, when trade winds are weaker, but are produced sporadically year-round (Navarro-Pérez \& Barton 2001, Hernández-Guerra et al. 2002), and might be responsible for much of the organic matter inputs into the region.

\section{Mesopelagic respiration}

In contrast to epipelagic $\mathrm{R}$, mean integrated microbial R in the mesopelagic zone (200 to $1000 \mathrm{~m}$ ) of the Canaries CTZ is of the same order of magnitude as in other oceanic regions (see review in Arístegui et al. 2003). However, the exponential decrease of $R$ with depth in the Canaries region is much sharper. This is observed when comparing the depth distribution of the normalised average cumulative respiration in our study with other regions (Fig. 8). In the Canaries region, $1 / 2$ of the mesopelagic respiration takes place between 200 and $450 \mathrm{~m}$, while the average for all the oceanic regions indicates that this occurs between 200 and $750 \mathrm{~m}$. One explanation for this could be that organic matter compounds transported to the mesopelagic zone are less refractory than in more open ocean regions. Also, the microbial community in the upper layers of the mesopelagic zone could be more efficient in the remineralisation of organic matter in the Canary Islands region than in other oceanic regions. The validity of either hypothesis is still unclear. Recently, it has been suggested that regional changes in export fluxes of POC result in part from differences in mineralisation rates in the surface waters (François et al. 2002). Productive regions in low 


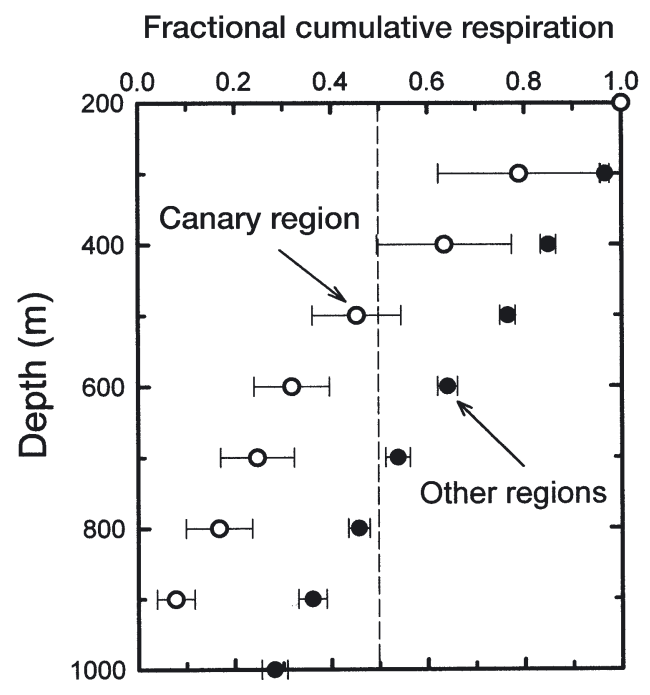

Fig. 8 . The depth distribution of the average $( \pm$ SE) cumulative respiration rate in the mesopelagic zone. Data from this study (Canary Islands region) are compared with data from other regions compiled from the literature (Arístegui et al. 2003). The dotted line indicates $50 \%$ of the water column (200 to $1000 \mathrm{~m}$ ) respiration. Note the sharp decrease in mesopelagic respiration in the Canaries, compared with the global average

latitudes tend to exhibit less mineralisation in the mesopelagic range than productive regions at higher latitudes (Antia et al. 2001, François et al. 2002). Organic carbon sinking out of the mixed layer in warm seas would experience more recycling than material in temperate or cold regions because of enhanced microbial activity in warmer waters. Hence, the amount of material available for respiration in the mesopelagic zone of warm seas would be lower. This might partly explain the high surface, but low deep-water, integrated $\mathrm{R}$ found in the Canaries region, as well as the sharp decreasing gradient in $\mathrm{R}$ in the upper mesopelagic zone.

An alternative and non-excluding hypothesis to explain the high surface respiration in this region is that upwelling of water from the aphotic zone, both at the African coast and in cyclonic eddies, brings up biorefractory DOC to the surface where it would suffer photochemical degradation and oxidation by microorganisms. Several studies (see revisions in Moran \& Zepp 2000 and Mopper \& Kieber 2002) have shown that UV radiation results in the cleavage of DOC into smaller, more biologically labile, organic compounds. These organic photoproducts significantly stimulate bacterial uptake, enhancing overall microbial R. Benner \& Biddanda (1998) hypothesised that deep-ocean biorefractory humic-rich DOC (that is dominant in upwelled waters) may be particularly susceptible to photochemical degradation, becoming more available to bacteria uptake. This hypothesis is supported by recent field studies on photochemical stimulation or inhibition of microbial activity using humic organic matter, carried out both on freshwater and marine ecosystems (Obernosterer et al. 1999, Tranvik \& Bertilsson 2001, Reitner et al. 2002).

\section{Contribution of POC and DOC to water column respiration}

The correlation analyses of ETS with DOC, POC and $\mathrm{chl} a$ in the upper $200 \mathrm{~m}$ suggests that respiration is mainly supported by particulate organic matter. This is more evident in the coastal stations where the upwelling waters with high chl $a$ and POC, but low DOC, concentrations present high R. However, a closer look at the vertical distributions of POC, DOC and ETS along the section suggests that, at certain stations, ETS may be based both on DOC and POC. This is observed in the upper $50 \mathrm{~m}$ between $14^{\circ}$ and $15^{\circ} \mathrm{W}$, or at the boundary of the anticyclonic eddy (A1) where relatively high ETS activity in the 0 to $150 \mathrm{~m}$ layer coincided with high DOC values (although POC was not sampled in the anticyclone).

In mesopelagic waters, the calculated (26.5\%) contribution of DOC to the oxygen anomaly (AOU) indicates that deep-water respiration is mainly based also on POC fluxes. Nevertheless, this percentage is higher than the global average of DOC contribution to mesopelagic R (Arístegui et al. 2002). DOC fluxes from the surface waters would correspond mainly to a combination of DOC delivered by vertical diffusive mixing (which would be respired in the upper mesopelagic zone) and by the excretion of plankton migrants in the deeper mesopelagic layers. Downward DOC flux through vertical diffusive mixing into the upper mesopelagic layers could be enhanced by island eddies and other mesoscale instabilities year-round, but there is still no information available to evaluate its overall impact. In addition, anticyclonic eddies could act as a trapping and removal mechanism of organic matter by increasing the vertical flux of POC. DOC could be either absorbed onto particles (Druffel et al. 1996), or aggregated by the action of surface charges and microbial activity to form amorphous particles of marine snow (e.g. Barber 1966), providing a mechanism whereby DOC is added to the sinking flux of particulate material at these convergence sites.

Convective mixing has been shown to be a significant transport process in areas of deep-water formation, and other areas experiencing seasonally intense convective mixing, where DOC seasonally accumulates, like the Sargasso, Mediterranean, Greenland or Norwegian seas (Hansell 2002). However, there is no evidence of either seasonal DOC accumulation 
figure small compared with the epipelagic respiration in the ESNA and CTZ (51 to $145 \mathrm{mmol} \mathrm{C} \mathrm{m}^{-2} \mathrm{~d}^{-1}$ ), but still significant in a global ocean context (Arístegui et al. 2003). Assuming that $26.5 \%$ of the mesopelagic respiration is based on DOC, an average $6 \mathrm{mmol} \mathrm{m} \mathrm{m}^{-2} \mathrm{~d}^{-1}$ of POC, would be respired and transported downwards. This represents the lower estimate of POC flux to the ocean floor in the UW region, derived from drifting sediment traps measurements during the same cruise (J. Arístegui et al. unpubl.) The calculated POC flux in open ocean waters is about 3 times higher than the annual average value recorded with moored sediment traps by Neuer et al. (2002) in the ESTOC time-series station, located about $100 \mathrm{~km}$ to the north of Gran Canaria Island. Recent studies using particle-reactive natural radio nuclides (e.g. ${ }^{234} \mathrm{Th}$ ) as a tracer for sinking particles, have convincingly demonstrated that moored sediment traps deployed in the mesopelagic zone may severely underestimate the particle flux (Buesseler 1991, Buesseler et al. 2000, Antia et al. 2001, Sholten et al. 2001, Yu et al. 2001). Nevertheless, it is also feasible that the POC fluxes are greater to the south than north of the archipelago, due to a higher $\mathrm{P}$ induced by cyclonic eddies.

The carbon balance summarised in Table 2 must be interpreted with some degree of caution. Compiled $\mathrm{P}$ values were derived either from ${ }^{14} \mathrm{C}$-uptake measurements (CTZ), oxygen evolution experiments (ESNA) or both (UW). Oxygen and ${ }^{14} \mathrm{C}$ measurements agree well in coastal UW waters (e.g. Arístegui \& Harrison 2002), but differ in more oceanic waters, where oxygen-based gross production is higher than ${ }^{14} \mathrm{C}$-based production (e.g. Marra 2002). Hence, $P$ in the CTZ region is probably somewhat higher than reported from ${ }^{14} \mathrm{C}$ measurements (Tables 1 \& 2).

Nevertheless, in spite of the uncertainties in the estimation of the different metabolic rates, the data from our study, and that compiled from the literature (Table 1), clearly show that both in the ESNA and particularly in the CTZ regions $\mathrm{R}$ is consistently higher than $\mathrm{P}$. To compensate for the metabolic imbalance between $\mathrm{P}$ and $\mathrm{R}$, the excess (non-respired and nonsedimented) production from the UW region must be advected to the CTZ region. Likewise, the latter region would act as a carbon source-by enhancing $\mathrm{P}$ - and an open ocean pump - by advecting nonrespired organic carbon to the ESNA. Future research in this region should aim to quantify the overall magnitude of the coastal UW open ocean transport. It should further include an evaluation of the role of cyclonic eddies in enhancing $\mathrm{P}$, and of anticyclones in trapping and transporting organic carbon down to the mesopelagic zone.
Acknowledgements. This work has been supported through the European Union (project CANIGO, MAS3.CT96-0060) and the Spanish government (project COCA, REN2000-U471CO2-02-MAR). We thank the officers and crew of the 'BIO Hespérides' as well as the staff of the Unidad Técnica de Mantenimiento (Consejo Superior de Investigaciones Científicas) for their invaluable help at sea. Comments by 2 anonymous reviewers have helped improve the manuscript.

\section{LITERATURE CITED}

Antia A, Koeve W, Fisher G, Blanz T and 11 others (2001) Basin-wide particulate carbon flux in the Atlantic Ocean: regional export pattern and potential for atmospheric $\mathrm{CO}_{2}$ sequestration. Global Biogeochem Cycles 15:845-862

Arístegui J, Harrison WG (2002) Decoupling of primary production and community respiration in the ocean: implications for regional carbon studies. Aquat Microb Ecol 29: 199-209

Arístegui J, Montero MF (1995) The relationship between community respiration and ETS activity in the ocean. J Plankton Res 17:1563-1571

Arístegui J, Montero MF (in press) Temporal and spatial changes in microplankton respiration and biomass in the Canary Islands: the effect of mesoscale variability. J Mar Syst

Arístegui J, Sangrà P, Hernández-León S, Cantón M, Hernández-Guerra A, Kerling JL (1994) Island-induced eddies in the Canary Islands. Deep-Sea Res I 41:1509-1525

Arístegui J, Tett P, Hernández-Guerra A, Basterretxea G and 8 others (1997) The influence of island-generated eddies on chlorophyll distribution: a study of mesoscale variation around Gran Canaria. Deep-Sea Res I 44:71-96

Arístegui J, Duarte CM, Agustí S, Doval M, Alvarez-Salgado XA, Hansell DA (2002) Dissolved organic carbon support of respiration in the dark ocean. Science 298:1967

Arístegui J, Agustí S, Duarte CM (2003) Respiration in the dark ocean. Geophys Res Lett 30(2):13.1-13.4

Baker AC (1970) The vertical distribution of euphausiids near Fuerteventura, Canary Islands (Discovery SOND cruise, 1965). J Mar Biol Assoc UK 50:301-342

Barber RT (1966) Interaction of bubbles and bacteria in the formation of organic aggregates in sea water. Nature 211: $257-258$

Barton ED, Arístegui J, Tett P, Cantón M and 18 others (1998) The transition zone of the Canary Current upwelling region. Prog Oceanogr 41:455-504

Barton ED, Basterretxea G, Flament P, Mitchelson-Jacob EG, Jones B, Arístegui J, Felix H (2000) Lee region of Gran Canaria. J Geophys Res 105:17173-17193

Basterretxea G (1994) Influencia de las estructuras oceanográficas mesoescalares sobre la producción primaria en la región Canaria. PhD thesis, Universidad de Las Palmas de Gran Canaria, Las Palmas de Gran Canaria

Basterretxea G, Arístegui J (2000) Mesoscale variability in phytoplankton biomass distribution and photosynthetic parameters in the Canary-NW African coastal transition zone. Mar Ecol Prog Ser 197:27-40

Basterretxea G, Barton ED, Tett P, Sangrá P, Navarro-Pérez E, Arístegui J (2002) Eddy and DCM response to wind shear in the lee of Gran Canaria. Deep-Sea Res I 49:1087-1101

Benner R, Biddanda B (1998) Photochemical transformations of surface and deep marine dissolved organic matter: effects on bacterial growth. Limnol Oceanogr 43:1373-1378

Bode A, Barquero S, Varela M, Braun JG, de Armas D (2001) Pelagic bacteria and phytoplankton in oceanic waters near 
the Canary Islands in summer. Mar Ecol Prog Ser 209:1-17

Buesseler KO (1991) Do upper-ocean sediment traps provide an accurate record of particle flux? Nature 353:420-423

Buesseler KO, Steinberg DK, Michaels AF, Johnson RJ, Andrews JE, Valdes JR, Price JF (2000) A comparison of the quantity and composition of material caught in a neutrally buoyant versus surface-tethered sediment trap. Deep-Sea Res I 47:277-294

Christensen JP, Owens TG, Devol AH, Packard TT (1980) Respiration and physiological state in marine bacteria. Mar Biol 55:267-276

Doval MD, Hansell DA (2000) Organic carbon and apparent oxygen utilization in the western South Pacific and the central Indian Oceans. Mar Chem 68:249-264

Druffel ERM, Bauer JE, Williams PM, Griffin S, Wolgast D (1996) Seasonal variability of particulate organic radiocarbon in the northeast Pacific Ocean. J Geophys Res 101:20543-20552

Duarte CM, Agustí S (1998) The $\mathrm{CO}_{2}$ balance of unproductive aquatic ecosystems. Science 281:234-236

Duarte CM, Agustí S, Arístegui J, González N, Anadón R (2001) Evidence for a heterotrophic subtropical northeast Atlantic. Limnol Oceanogr 46:425-428

Ducklow HW, Steinberg DK, Buesseler KO (2001) Upper ocean carbon export and the biological pump. Oceanography 14:59-67

Falkowski PG, Ziemann D, Kolber Z, Bienfang PK (1991) Role of eddy pumping in enhancing primary production in the ocean. Nature 353:55-58

François R, Honjo S, Krishfield R, Manganini S (2002) Running the gauntlet in the twilight zone: the effect of midwater processes on the biological pump. US JGOFS Newsletter 11:4-6

Gabric AJ, García L, van Camp L, Nykjaer L, Eifler W, Schrimpf W (1993) Offshore export of shelf production in the Cape Blanc (Mauritania) giant filament as derived from Coastal Zone Color Scanner imagery. J Geophys Res 98:4697-4712

González N, Anadón R, Mouriño B, Fernández E, Sinha B, Escánez J, de Armas D (2001) The metabolic balance of plankton community in the N Atlantic Subtropical Gyre: the role of mesoscale instabilities. Limnol Oceanogr 46: 946-952

Grall JR, Le Corre P, Treguer P (1982) Short-term variability of primary production in coastal upwelling of Morocco. Rapp P-V Reun Cons Int Explor Mer 180:221-227

Hansell DA (2002) DOC in the global ocean carbon cycle. In: Hansell DA, Carlson CA (eds) Biogeochemistry of marine dissolved organic matter. Elsevier, California, p 685-715

Hansell DA, Carlson CA (2001) Biogeochemistry of total organic carbon and nitrogen in the Sargasso Sea: control by convective overturn. Deep-Sea Res II 48:1649-1667

Harrison WG, Arístegui J, Head EJ, Li WKW, Longhurst AR, Sameoto DD (2001) Basin-scale variability in plankton biomass and community metabolism in the sub-tropical North Atlantic Ocean. Deep-Sea Res II 48:2241-2269

Hedges JI, Baldock JA, Gélinas Y, Lee C, Peterson ML, Wakeham SG (2002) The biochemical and elemental compositions of marine plankton: A NMR perspective. Mar Chem 78:47-63

Hernández-Guerra A, Machín F, Antoranz A, CisnerosAguirre J and 9 others (2002) Temporal variability of mass transport in the Canary Current. Deep-Sea Res II 49: 3415-3426

Hernández-León S, Gómez M, Pagazaurtundua M, PortilloHahnefeld A, Montero I, Almeida C (2001) Vertical distribution of zooplankton in Canary Island waters: implica- tions for export flux. Deep-Sea Res I 48:1071-1092

Hidaka K, Kawaguchi K, Murakamo M, Takahashi M (2001) Downward transport of organic carbon by diel migratory micronekton in the western equatorial Pacific: its quantitative and qualitative importance. Deep-Sea Res I 48: 1923-1939

Holm-Hansen O, Strickland JDH, Williams PM (1966) A detailed analysis of biologically important substances in a profile off Southern California. Limnol Oceanogr 11: 548-561

Kenner RA, Ahmed SI (1975) Measurements of electron transport activities in marine phytoplankton. Mar Biol 33: $119-127$

Longhurst AR (1976) Vertical migration. In: Cushing DH, Walsh JJ (eds) The ecology of the seas. Blackwell Scientific Publications, Oxford, p 116-137

Marra J (2002) Approaches to the measurement of plankton production. In: Williams PJLeB, Thomas DN, Reynolds CS (eds) Phytoplankton productivity. Blackwell Science Publications, Oxford, p 78-108

McGillicuddy DJ Jr, Robinson AR, Siegel DA, Jannasch HW and 5 others (1998) Influence of mesoscale eddies on new production in the Sargasso Sea. Nature 394:263-266

Minas HJ, Codispoti LA, Dugdale RC (1982) Nutrients and primary production in the upwelling region off Northwest Africa. Rapp P-V Reun Cons Int Explor Mer 180: $148-183$

Mopper K, Kieber DJ (2002) Photochemistry and the cycling of carbon, sulfur, nitrogen and phosphorus. In: Hansell DA, Carlson CA (eds) Biogeochemistry of marine dissolved organic matter. Elsevier, California, p 455-508

Moran MA, Zepp RC (2000) UV radiation effects on microbes and microbial processes. In: Kirchman DL (ed) Microbial ecology of the oceans. John Wiley \& Sons, New York, p 201-228

Navarro-Pérez E, Barton ED (2001) Seasonal and interannual variability of the Canary Current. Sci Mar 65(Suppl 1): 205-213

Neuer S, Freudenthal T, Davenport R, Llinás O, Rueda MJ (2002) Seasonality of surface water properties and particle flux along a productivity gradient off N.W. Africa. DeepSea Res II 49:3561-3576

Obernosterer I, Reitner B, Herndl GJ (1999) Contrasting effects of solar radiation on dissolved organic matter and its bioavailability to marine bacterioplankton. Limnol Oceanogr 44:1645-1654

Pacheco MM, Hernandez-Guerra A (1999) Seasonal variability of recurrent phytoplankton pigment patterns in the Canary Islands area. Int J Remote Sens 20:1405-1418

Packard TT (1971) The measurement of respiratory electron transport activity in marine phytoplankton. J Mar Res 29: 235-244

Packard TT, Denis M, Rodier M, Garfield P (1988) Deepocean metabolic $\mathrm{CO}_{2}$ production: calculations from ETS activity. Deep-Sea Res I 35:371-382

Pelegrí JL, Arístegui J, Cana L, González-Dávila M and 6 others (in press) Coupling between the open ocean and the coastal upwelling region off Northwest Africa: Water recirculation and offshore pumping of organic matter. J Mar Syst

Pugh PR (1974) The vertical distribution of siphonophores collected during the SOND cruise, 1965. J Mar Biol Assoc UK 54:25-90

Reitner B, Herzig A, Herndl GJ (2002) Photoreactivity and bacterioplankton availability of aliphatic versus aromatic amino acids and a protein. Aquat Microb Ecol 26:305-311

Robinson C, Serret P, Tilstone G, Teira E, Zubkov V, Rees AP, 
Woodward EMS (2002) Plankton respiration in the Eastern Atlantic Ocean. Deep-Sea Res I 49:787-813

Roe HSJ (1972) The vertical distribution and diurnal migrations of Calanoid copepods collected on the SON Cruise 1965. I. The total population and general discussion. J Mar Biol Assoc UK 52:277-314

Roe HSJ (1974) Observations on the diurnal vertical migrations of an oceanic animal community. Mar Biol 28:99-113

Rudyakov YA (1979) Diurnal vertical migrations of pelagic animals in the Canary Islands. Oceanology 19:196-199

Scholten JC, Fietzke J, Vogler S, Rutgers van der Loeff MMR and 6 others (2001) Trapping efficiencies of sediment traps from the deep Eastern North Atlantic: the ${ }^{230}$ Th calibration. Deep-Sea Res II 48:2383-2408

Serret P, Robinson C, Fernández E, Teira E, Tilstone G (2001) Latitudinal variation of the balance between plankton photosynthesis and respiration in the eastern Atlantic Ocean. Limnol Oceanogr 46:1642-1652

Serret P, Fernández E, C Robinson (2002) Biogeographic differences in the net ecosystem metabolism of the open ocean. Ecology 83:3225-3234

Sharp J, Peltzer ET (1993) Procedures subgroup report. Mar Chem 41:37-49

Steinberg DK, Carlson CA, Bates NR, Goldthwait SA, Madin LP, Michaels AF (2000) Zooplankton vertical migration and the active transport of dissolved organic and inorganic carbon in

Editorial responsibility: William $\mathrm{Li}$,

Dartmouth, Nova Scotia, Canada the Sargasso Sea. Deep-Sea Res I 47:137-158

Steinberg DK, Carlson CA, Bates NR, Johnson RJ, Michaels AF, Knap AH (2001) Overview of the US JGOFS Bermuda Atlantic Time-series Study (BATS): a decade-scale look at ocean biology and biogeochemistry. Deep-Sea Res II 48: $1405-1447$

Thomas C, Cauwet G, Minster JF (1995) Dissolved organic carbon in the equatorial Atlantic Ocean. Mar Chem 49: 155-169

Tranvik LJ, Bertilsson S (2001) Contrasting effects of solar UV radiation on dissolved organic sources for bacterial growth. Ecol Lett 4:458-463

UNESCO (1994) Protocols for the Joint Global Ocean Flux Study (JGOFS) core measurements. Manual and guides, Vol 29. Intergovernmental Oceanographic Commission, UNESCO, Paris

Weiss RF (1970) The solubility of nitrogen, oxygen and argon in water and seawater. Deep-Sea Res 17:721-735

Yentsch CS, Menzel DW (1963) A method for the determination of phytoplankton chlorophyll and phaeophytin fluorescence. Deep-Sea Res I 10:221-231

Yu EF, François R, Bacon MP, Honjo S, Fleer AP, Manganini SJ, Rutgers van der Loeff MMR, Ittekot V (2001) Trapping efficiency of bottom-tethered sediment traps estimated from the intercepted fluxes of ${ }^{230} \mathrm{Th}$ and ${ }^{231} \mathrm{~Pa}$. Deep-Sea Res I 48:865-889

Submitted: March 6, 2003; Accepted: August 14, 2003 Proofs received from author(s): October 20, 2003 